\title{
Nuclear transfer: a new tool for reproductive biotechnology in cattle
}

\author{
Yvan HEYMAN* \\ UMR INRA-ENVA, Biologie du Développement et Biotechnologie, 78352 Jouy-en-Josas, France
}

\begin{abstract}
Recent evolutions of somatic cloning by nuclear transfer are reported, especially in the bovine species where potential applications are underway for biomedicine in association with transgenesis, or for agriculture by improving livestock. The overall efficiency of this biotechnology remains low in terms of viable offspring, but significant progress has been achieved on the different steps of the technique. However, the in vivo development of bovine blastocysts derived from somatic nuclear transfer is characterised by some important features that lead to the "cloning syndrome". Important losses occur during the peri-implantation period and further late foetal loss is observed in association with the Large Offspring Syndrome. About 60-70\% of the cloned calves born survive normally to the adult stage and present an apparently normal physiology. Recent data already available on bovine somatic clones of both sexes indicate that they have a zootechnical performance similar to non cloned animals and they are able to reproduce normally without the pathologies associated to cloning thus confirming that the deviations observed in clones are of epigenetic origin and not transmitted to the progeny.
\end{abstract}

biotechnology / reproduction / cattle / somatic cloning / nuclear transfer / efficiency

\section{INTRODUCTION}

In cattle, biotechnology of reproduction started around 1950 with the development of Artificial Insemination (AI), followed by the use of embryo transfer since the nineteen-seventies (considered as the second generation of biotechnology). More recently, bovine cloning from somatic cells resulting in the birth of live offspring has proven to be feasible while its efficiency is still very low. The first calves derived from somatic cell nuclear transfer were born in 1998 nearly simultaneously in the USA [1] and in France at INRA [2]. Concerning somatic cloning in domestic mammals, since the birth of Dolly the sheep [3], the bovine species is undoubtedly the species which is the most involved and advanced for somatic cloning. From the different research groups and companies, it can be estimated that up to the year 2004, about 1500 calves have been obtained through somatic nuclear transfer worldwide, mainly in North America, Japan, New Zealand and Europe but also in other countries from South America or Asia. However this number of cloned calves born is still negligible compared to the impact of other reproductive biotechnologies, for instance nearly 500000 embryo

\footnotetext{
* Corresponding author: yvan.heyman@jouy.inra.fr
} 
transfers are performed each year in cattle from in vivo or in vitro produced embryos [4]. However, the present status of somatic cloning is characterised by a low efficiency and is still in its improvement phase, this procedure of nuclear transfer should be in the future integrated in the bovine ART tool box.

\section{POTENTIAL APPLICATIONS FOR BOVINE SOMATIC CLONING}

First of all, nuclear transfer should be considered as a wonderful tool for basic research for the investigation of cell biology and reprogramming. The bovine embryo offers several advantages with relatively late activation of its genome and late implantation compared to the mouse model.

The generation of sets of clones can be used as more homogeneous animal models for experimental purposes allowing to reduce the number of cattle necessary for long-term studies on pathology or nutrition projects for example. To really evaluate a treatment effect on the physiology and zootechnical performances of cattle, variability due to genetic difference between animals can be reduced by the use of sets of clones, especially if the trait is of high heritability, milk production for instance [5].

Somatic cloning may contribute to the preservation of endangered breeds and while paradoxical, nuclear transfer can be considered as another tool for the strategy of conservation and utilisation of biodiversity. Many examples are arising in this field and some have proven to be feasible. Recently in New Zealand, nuclear transfer has been used to clone the unique female of the extinct bovine breed "Enderby Island" [6] allowing to obtain more than 20 females. These females will be bred by semen from different bulls that were frozen-stored before the extinction of this breed. Furthermore, the bovine oocyte can be used as a recipient of somatic nuclei from other endangered species. Using this approach of inter-spe- cific nuclear transfer, Gaur fibroblasts (Bos gaurus) fused to bovine enucleated oocytes (Bos taurus) have resulted into a deadborn offspring of the Bos gaurus genotype and chimeric Bos taurus mitochondria as an interspecies model [7].

For cattle breeding and selection, somatic cloning can bring several potential advantages to existing breeding schemes: the use of clones could help to know more precisely the genetic value of progenitors. Prospective calculations by geneticists indicate that in dairy breeds, genetic value evaluated by milk production of a set of 5 female clones is as precise as that of milk performance of at least 25 non-cloned daughters of a given bull, and annual genetic progress could be improved by $20 \%$ [5]. Another example is given by the fact that genocopies of a highly valuable AI bull can be obtained through nuclear transfer in case of accidental death or severe disease of this progenitor, provided some cells have previously been frozen-stored. The possibility to secure this risk was first demonstrated in Canada with the birth of the clone bull Starbuck II using donor cells from the original bull when it died.

Multiplication of specific phenotypes by cloning is another possibility provided the cost of the technique is reduced and its application well-controlled. Cells taken from a small muscle biopsy on carcasses of slaughtered animals 2 or 3 days after death can efficiently be used as donor cells for cloning and widespread dissemination of desirable carcass traits.

However, potential applications of bovine cloning go well beyond the replication of valuable genitors. Since targeted genetic modifications can be made in donor cells prior to nuclear transfer, cloning can be used to more efficiently generate transgenic animals for different purposes: therapeutic protein production in milk and blood for bio-medicine, or genetically modified livestock for improved animal production in which undesirable traits will be eliminated and other positive traits will be added. 
Applications include safer, healthier and finally cheaper cattle products. Deletion of the PrP (Prion Protein) gene has been achieved in ovine fibroblasts before cloning resulting in lambs carrying the gene deletion [8]. The PrP gene is directly associated with BSE in cattle. By "knockingout" this gene, the resulting prion free livestock should be resistant to disease such as BSE. Such projects are currently being developed to increase disease resistance and to get safer products [9]. Other projects concern not only animal food production but other applications for industry such as production of biomaterials through improved transgenesis efficiency. This is the case with spider silk proteins secreted in the milk of transgenic goats. Environmental concerns may also be addressed by combining cloning and transgenesis to generate pigs that produce less phosphate in their faeces.

\section{A BRIEF OVERVIEW OF THE TECHNIQUE AND FACTORS AFFECTING THE CLONING PROCESS}

A clone can be defined as a set of two ore more individuals with identical genetic make up derived from asexual reproduction from a single common parent. The term clone has been used to designate animals produced by the technique of nuclear transfer. In this process, the nucleus of a donor cell (karyoplast) is transferred to a recipient cell (cytoplast) in which the genetic material has been removed. The whole procedure for bovine somatic cloning includes several steps illustrated in Figure 1.

\subsection{Preparation of recipient oocyte cytoplasm}

Oocytes arrested at the second meiotic division have become the cytoplasm of choice [10]. In cattle, large numbers of oocytes can be obtained through in vitro maturation of VG stage oocytes recovered from antral follicles on slaughterhouse ova- ries or by ovum pick up on the same animal. In vitro maturation of bovine oocytes is now routinely performed in many laboratories and we are grateful to the pioneer work of Pr C. Thibault on the physiology of mammalian oocyte maturation [11].

\subsection{Donor cells}

A biopsy of tissue can be taken from the selected donor animal, usually a small skin biopsy constitutes a non invasive way of getting genetic material from a valuable animal without sex or age limitation cloning. From the biopsy, cell culture is generally established in vitro in order to multiply and store at the frozen state. In our laboratory, we have used fibroblasts derived from small skin biopsies taken from the ears of different adult donors. The cells were in vitro cultured over several passages and frozen stored before nuclear transfer [2]. However numerous studies provided evidence that somatic cells from a variety of tissues can be used for somatic cell nuclear transfer [12, 13].

\subsection{Reconstruction by micromanipulation}

Each individual donor cell isolated from the culture plate is inserted into the perivitelline space of the enucleated recipient oocyte by micromanipulation and then introduced into the oocyte cytoplasm by electrostimulation with a DC pulse that makes the adjacent membranes fuse. The electric pulse not only induces the fusion of the somatic cell with the oocyte cytoplasm to form a new complex but also provokes an important release of intracellular calcium that initiates the process of activation. Activation is a key step and can also be induced by calcium ionophores (ionomycin) and must be completed by addition of protein synthesis inhibitors such as cycloheximide or protein kinase inhibitors (6 DMAP) to deplete the oocyte factor MPF (Maturation Promoting Factor) which is responsible for the metaphase II block. 


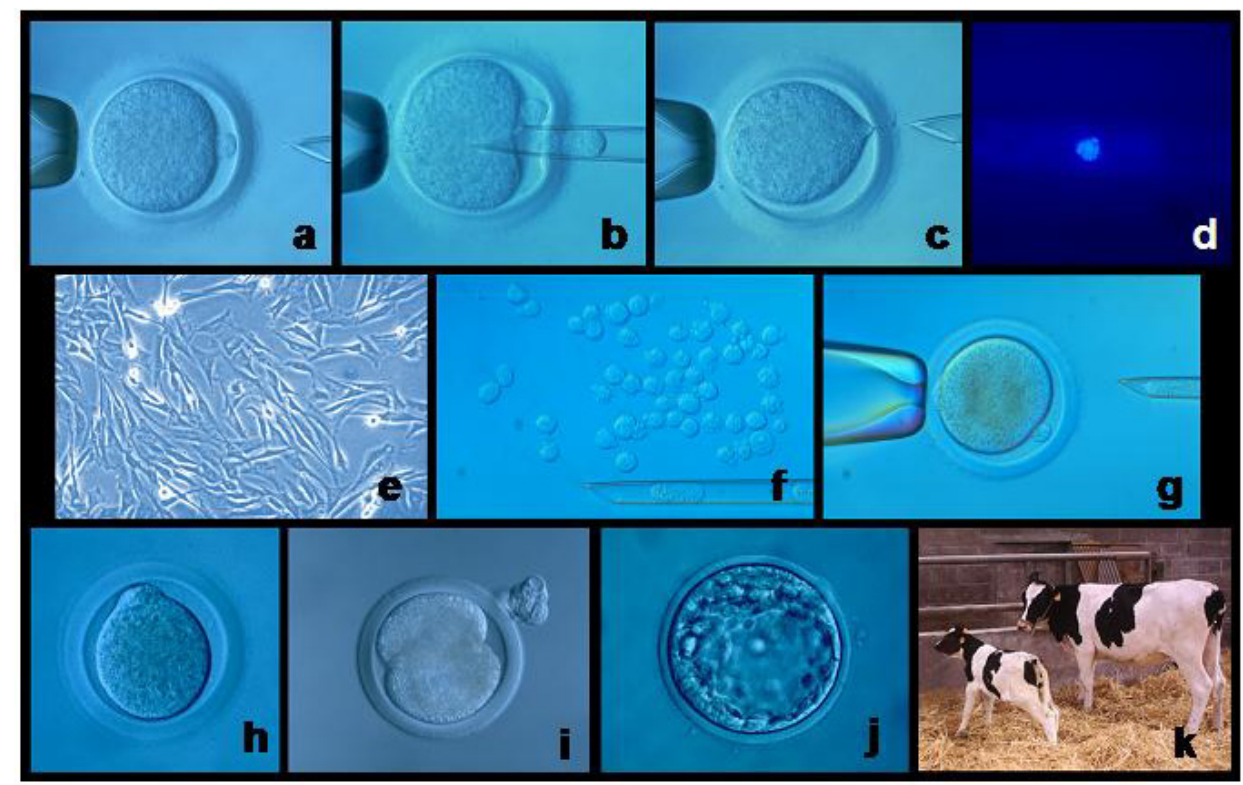

Figure 1. Illustration of the different steps of the nuclear transfer procedure. (a) Metaphase II stage oocyte before enucleation. (b) Aspiration of polar body and adjacent oocyte cytoplasm. (c) Enucleated oocyte. (d) Fluorescence control of the presence of metaphase chromosomes inside the micromanipulation pipette after DNA staining. (e) Bovine fibroblast culture from skin biopsy. (f) Donor cells isolated from the fibroblast culture. (g) Insertion of a donor cell under the zona pellucida of an enucleated oocyte. (h) Fusion of the donor cell with the recipient cytoplasm. (i) First cleavage of the reconstituted embryo. (j) Nuclear transfer blastocyst developed in vitro. (k) Newborn somatic cloned calf together with the donor animal.

\subsection{In vitro culture of reconstituted embryos}

After fusion and activation, nuclear transfer embryos are developed in vitro up to the blastocyst stage using a variety of culture systems routinely used for bovine IVF embryos. In our laboratory reconstituted embryos are cocultured in microdrops of B2 medium with vero cells at $39^{\circ} \mathrm{C}$ under a controlled $\mathrm{CO}_{2}$ atmosphere [14].

\subsection{Factors affecting cloning}

Efficiency of cloning depends upon a large number of factors related to the technique itself but mainly to the biological parameters related to the cell cycle co-ordination between the donor nucleus and recipient oocyte, artificial activation proce- dure, or in vitro culture conditions for the reconstructed embryo. Several recent reviews discuss these issues in detail $[15,16]$. According to the type of donor cells and the procedure used, compiled data from the literature indicate that in the bovine species, reconstructed embryos are able to develop in vitro into blastocysts at a rate comprised between $20 \%$ and $60 \%$ which is becoming close to that obtained after IVF. Blastocysts derived from nuclear transfer of fibroblasts are morphologically normal and have similar kinetics of in vitro development compared to blastocysts derived from IVF. However, as early as day 7 , nuclear transfer blastocysts may have altered gene expression as shown by Wrenzycki et al. [17]. This may explain further differences in their potential for full term development. A 


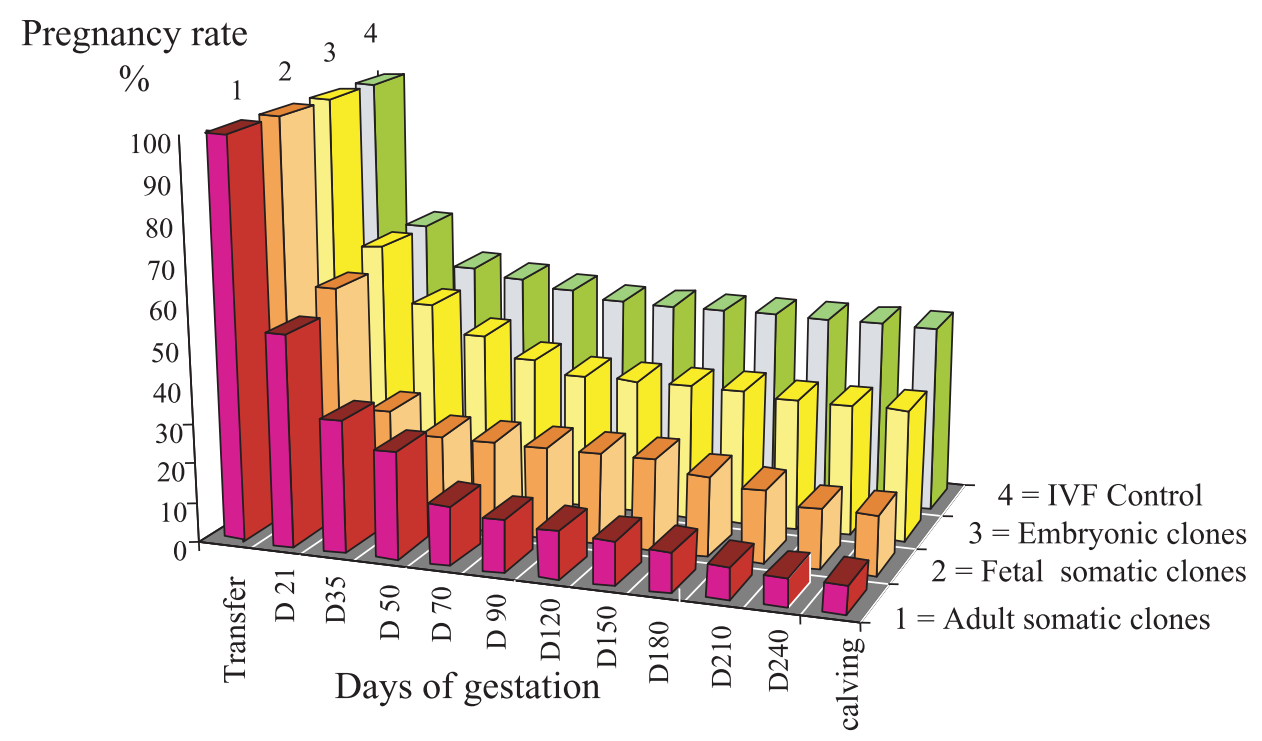

Figure 2. Evolution of pregnancy profiles in bovine recipients after transfer of cloned embryos.

study conducted in our laboratory to compare the development of bovine cloned embryos from fibroblasts of two different genetic origins A and B, clearly showed that the reconstituted embryos cleaved at the same rate and the in vitro development to the blastocyst stage was not significantly different $(36.1 \%$ and $42.9 \%$ for genotypes $\mathrm{A}$ and $\mathrm{B}$ respectively, $P>0.05$ ). However pregnancy rates after transfer of these NT blastocysts were significantly lower from implantation up to term in cows carrying A clones, resulting in a calving rate as low as $2.3 \%$ compared to $25.0 \%$ for B clones $(P<$ $0.001)$. These results may indicate that different genotypes within the same breed have no effect on early in vitro development of NT embryos but a very high incidence on further in vivo development potential [18].

\section{IMPORTANCE OF EMBRYONIC AND FOETAL DEATH}

After transfer of somatic nuclear transfer blastocyts into the uterus of recipient cows, peri implantation losses are important and the proportion of initiated pregnancies that fail during this period can be estimated to $50 \%[1,19]$. In a comparative study, we monitored the evolution of pregnancy in groups of recipients receiving single embryos derived from somatic or embryonic nuclei or control IVF embryos, using repeated scanning and Pregnancy Serum Protein PSP 60 assays (Fig. 2). It was quite clear that initiated pregnancy rates in the different groups were similar as assessed by plasma progesterone level in maternal plasma by day 21 but we observed that the frequency of early foetal loss before 2 months was twice higher in the groups of recipients carrying somatic NT embryos compared to embryonic NT or control IVF [20]. These early losses are frequently associated with functional deficiencies occurring at the onset of placentation characterised by abnormal vascularisation of extra embryonic tissue and reduced number of placentomes.

After implantation, foetal and placental development in recipients can be monitored 
by repeated ultrasonography. This technique detects the occurrence of $44 \%$ of late gestation losses between day 90 and calving in recipients carrying adult somatic clones when the rate of abortion in normal bovine sexual reproduction is usually very limited and less than 5\% after the first trimester. Interestingly, maternal levels of PSP 60 over the first 4 months of pregnancy appeared to be significantly increased in recipients where a case of pathologic pregnancy was detected by ultrasonography in late gestation [20]. In this situation, the protein PSP60 which is secreted by binucleated cells of the placenta could be a good marker to predict the occurrence of abnormal development in those recipients carrying somatic clones. One of the most frequently encountered syndromes during pathologic pregnancy is hydrallantoiis or hydrops characterised by the presence of an acute accumulation of fluid in the allantoic, enlarged placentomes and oversized foetus. This pathology is a serious animal welfare issue for recipients carrying somatic clones since its frequency is considerably increased. Data from New Zealand indicate that after somatic nuclear transfer, $27 \%$ pregnancies over 120 days developed hydrops [21]. This is much higher than that observed after natural mating or $\mathrm{AI}(0.02$ to $0.6 \%$ ). Increased incidence of hydrallantoïs in somatic cloned pregnancies is probably also related to inappropriate expression of some imprinted genes and the causes of embryonic and foetal death are analysed in an exhaustive review by $\operatorname{PrC}$. Thibault [22].

\section{POSTNATAL DEVELOPMENT AND PERFORMANCE OF OFFSPRING}

Calving and the peri-natal period are critical periods in the process of obtaining normal live calves through somatic nuclear transfer. Post natal losses at birth or during the first few days of life are associated with prolonged gestation, dystocia [12, 19, 23] or occurrence of the Large Offspring Syndrome (LOS). We have observed in our studies [24] that $13.3 \%$ of the somatic clone calves born are affected by LOS, but higher rates have been reported by other groups in Japan [12]. This syndrome results from epigenetic modifications arising from imprinted genes such as IGFR2 shown to be associated with foetal overgrowth in sheep [25]. Such epigenetic changes occurring in early embryo development are the consequences of the different in vitro manipulations. These modifications may be propagated throughout development and affect gene expression not only during gestation or during the postnatal period but also into adulthood as shown in the mouse model [26].

In cloned calves at birth, a variety of dysfunctions and anomalies such as respiratory distress, cardiopathology, abnormal kidneys as well as hypertrophic liver have been reported [1, 27]. Further post-natal mortality occurs after the 1 week and up to the 4 month period; a wide range of other illnesses have been reported in clones, including infections, like ruminitis and abomasomitis [6] or coccidiosis and infection following trauma [18]. We have reported the case of one somatic clone diagnosed with thymic aplasia directly related to the cloning process [23].

Finally the proportion of somatic cloned calves born that are able to develop normally into adults is limited to $50-70 \%$ according to various groups. In our laboratory, the health status of cloned cattle was investigated by Chavatte-Palmer et al. [28] at different ages on 59 calves born. Sixtytwo per cent of them developed into apparently normal adults.

Increasing data on zootechnical parameters of cloned cattle are becoming available. Growth rates are reported to be normal [29]. We compared the daily gain of three sets of female clones to that of control AI heifers born and raised on the same farm under similar feeding and management and found no difference in growth rate (Tab. I). Furthermore, within each clone, daily gain was not influenced by the high or low birth weight of the calves. This indicates that the 
Table I. Mean \pm SD body weight gain in clones according to genetic origin and contemporary controls.

\begin{tabular}{lccccc}
\hline Daily gain & $\begin{array}{c}\text { Clone A } \\
N=8(12 \mathrm{mo})\end{array}$ & $\begin{array}{c}\text { Control 1 } \\
N=10(12 \mathrm{mo})\end{array}$ & $\begin{array}{c}\text { Clone B } \\
N=6(15 \mathrm{mo})\end{array}$ & $\begin{array}{c}\text { Clone C } \\
N=9(15 \mathrm{mo})\end{array}$ & $\begin{array}{c}\text { Control } 2 \\
N=10(15 \mathrm{mo})\end{array}$ \\
\hline $\mathrm{kg} \cdot \mathrm{day}^{-1} \pm \mathrm{SD}$ & $0.701 \pm 0.064$ & $0.804 \pm 0.113$ & $0.782 \pm 0.041$ & $0.711 \pm 0.061$ & $0.766 \pm 0.089$ \\
\hline
\end{tabular}

prenatal environment that allowed for perinatal oversize does not continue after birth in the cloned calf [24].

The reproductive characteristics of cloned heifers derived from adult somatic cloning have been evaluated in terms of puberty, follicular dynamics, hormone profiles and are not different from that of control noncloned animals [30]. Cloned heifers have proven to be able to reproduce after natural mating or AI; Lanza et al. [31] reported an $83 \%$ conception rate on first insemination. Similarly, limited numbers of cloned bulls have been evaluated for libido, semen production quantitatively and qualitatively and preliminary results suggest no deleterious effect of cloning on the semen picture of these cloned sires [24].

To address potential food safety concerns of products such as milk or meat derived from cloned animals, research programmes are conducted. A recent study by Walsh et al. [32] concluded that the gross chemical composition of milk from cloned cows is similar to that of non cloned ones. Preliminary results from Japan on digestibility, composition, feeding value or allergenicity of meat obtained from somatic cloned animals indicate that the biological/ biochemical properties of their meat are similar to that of conventional animals but these results have to be confirmed on larger numbers of animals before drawing any conclusion about food safety [33].

Somatic cloned cattle of both sexes have now reached adulthood in different institutes worldwide, and are still under investigation for other observations such as detection of possible long term effects of NT or longevity of the animals. Data already available indicate they have similar per- formance as non cloned controls and are able to reproduce normally. In contrast to the cloned generation, the offspring of clones obtained following sexual reproduction are phenotypically and clinically normal. This confirms that the deviations observed in clones are of epigenetic origin and are not transmitted to the progeny as already demonstrated in the mouse model [34].

\section{CONCLUSION}

It is worthwhile to remember that somatic cloning by nuclear transfer in mammals is still a recent discipline since in the bovine species for example the first calves were obtained in 1998. In the past few years however, tremendous progress has been achieved in the different steps of the procedure as well as the oocyte/nucleus interactions, activation or culture. Meanwhile the overall efficiency is still low, we can consider that during a 5 year period, the results have well improved (Tab. II). It is now well established that cattle clones when they develop into adults present an apparently normal physiology. They reproduce normally and have zootechnical performances similar to non cloned animals. It also seems clear that the pathologies associated to somatic cloning during pre and post natal life of the cloned animal are of epigenetic origin and not transmitted to the progeny of the clones. It is still too early to conclude about the longevity of cloned cattle and this is why ambitious research programmes have to be developed on possible long term effects of nuclear transfer together with risk assessment studies, welfare and societal concerns, so that appropriate safeguards will ensure 
Table II. Progress of bovine somatic cloning efficiency within a period of 5 years.

\begin{tabular}{lcc}
\hline & Year 1998-1999 & Year 2003-2004 \\
\hline Mean in vitro development rate & $17.5 \%$ & $36.8 \%$ \\
(blastocysts/reconstituted eggs) & $(341 / 1954)$ & $(1027 / 2792)$ \\
In vivo development & $6.3 \%$ & $15 \%$ \\
(calves born/embryos transferred) & $(14 / 220)$ & $(222 / 1510)$ \\
Overall efficiency & $1.1 \%$ & $5.5 \%$ \\
(calves born/100 somatic nuclei) & & \\
\hline
\end{tabular}

safe and responsible applications of cloning in animal husbandry.

\section{REFERENCES}

[1] Cibelli JB, Stice SL, Golueke PJ, Kane JJ, Jerry J, Blackwell C, Ponce de Leon FAP, Robl JM. Cloned transgenic calves produced from nonquiescent fetal fibroblast. Science 1998, 280: 1256-1258.

[2] Vignon X, Chesné P, LeBourhis D, Fléchon JE, Heyman Y, Renard JP. Developmental potential of bovine embryos reconstructed from enucleated matured oocytes fused with cultured somatic cells. C R Acad Sci Paris, Life Sci 1998, 321: 735-745.

[3] Wilmut I, Schnieke AE, McWhir J, Kind AJ, Campbell KHS. Viable offspring derived from fetal and adult mammalian cells. Nature 1997, 385: 810-813.

[4] Thibier M. Data retrieval committee annual report. IETS Newsletter Dec 2004, p 13-20.

[5] Colleau JJ, Heyman Y, Renard JP. Les biotechnologies de la reproduction chez les bovins et leurs applications réelles ou potentielles en sélection. Productions Animales 1998, 11: 41-56.

[6] Wells D, Misica P, Tervit HR, Vivanco WH. Adult somatic cell nuclear transfer is used to preserve the last surviving cow of Enderby Island cattle breed. Reprod Fertil Dev 1998, 10: 369-378.

[7] Dindot S, Farin P, Farin C, Romano J, Walker S, Long C, Piedrahita J. Epigenetic and genomic imprinting analysis in nuclear transfer derived Bos gaurus/Bos indicus hybrid fetuses. Biol Reprod 2004, 71: 470-478.

[8] Denning C, Burl S, Ainslie A, Bracken J, Dinnyes A, Fletcher J, King T, Ritchie M, Ritchie WA, Rollo M, DeSousa P, Travers A, Wilmut I. Nat. Biotechnol 2001, 19: 559-562.
[9] Forsberg EJ. Commercial applications of nuclear transfer cloning: three examples. Reprod Fertil Dev 2005, 17: 59-68.

[10] Campbell KHS, Loi P, Otaegui P, Wilmut I. Cell cycle coordination in embryo cloning by nuclear transfer. Rev Reprod 1996, 1: 40-46.

[11] Thibault C, Szollosi D, Gerard M. Mammalian oocyte maturation. Reprod Nutr Dev 1987, 27: 865-886.

[12] Kato Y, Tani T, Tsunoda Y. Cloning of calves from various somatic cell types of male and female adult, newborn and fetal cows. J Reprod Fertil 2000, 120: 231-237.

[13] Zakhartchenko V, Alberio R, Stojkovic M, Prelle K, Schernthaner W, Stojkovic P, Wenigerkind H, Wanke R, Düchler M, Steinborn R, Mueller M, Brem G, Wolf E. Adult cloning in cattle: Potential of nuclei from a permanent cell line and from primary cultures. Mol Reprod Dev 1999, 54: 264-272.

[14] Menck C, Guyader-joly C, Peynot N, LeBourhis D, Lobo RB, Renard JP, Heyman Y. Beneficial effect of vero cells for developing IVF bovine eggs in two different coculture systems. Reprod Nutr Dev 1997, 37: 141-150.

[15] Renard JP, Zhou Q, LeBourhis D, ChavattePalmer P, Hue I, Heyman Y, Vignon X. Nuclear transfer technologies: between successes and doubts. Theriogenology 2002, 66: 6-13.

[16] Galli C, Lagutina I, Lazzari G. Introduction to cloning by nuclear transplantation. Cloning and stem cells 2003, 5: 223-232.

[17] Wrenzycki C, Herrman D, Lucas-Hahn A, Korsawe K, Lemme E, Niemann, H. Messenger RNA expression patterns in bovine embryos derived from in vitro procedures and their implications for development. Reprod Fertil Dev 2005, 17: 23-35.

[18] Vignon X, LeBourhis D, Laloy E, Lavergne Y, Servely JL, Richard C, Renard JP, Heyman Y. A comparison of the development of bovine embryos cloned from fibroblasts of 
two different genetic origin. In: Proc 19th AETE meeting, 2003, p 218.

[19] Wells DN, Misica PM, Tervit HR. Production of cloned calves following nuclear transfer with cultured adult mural granulosa cells. Biol Reprod 1999, 60: 996-1005.

[20] Heyman Y, Chavatte-Palmer P, LeBourhis D, Camous S, Vignon X, Renard JP. Frequency and occurrence of late gestation losses from cattle cloned embryos. Biol Reprod 2002, 66: 6-13.

[21] Oback B, Wells D. Cloning cattle. Cloning Stem Cells 2003, 5: 243-256.

[22] Thibault C. Recent data on the development of cloned embryos derived from reconstructed eggs with adult cells. Reprod Nutr Dev 2003, 43: 303-324.

[23] Renard JP, Chastant S, Chesne P, Richard C, Marchal J, Cordonnier N, Chavatte Palmer P, Vignon X. Lymphoid hypoplasia and somatic cloning. Lancet 1999, 353: 1489-1491.

[24] Heyman Y, Richard C, Rodriguez-Martinez $\mathrm{H}$, Lazzari G, Chavatte-palmer P, Vignon X, Galli C. Zootechnical performance of cloned cattle and offspring: preliminary results. Cloning Stem Cells 2004, 6: 111-120.

[25] Young LE, Fernandes K, Mc Evoy TG, Butterwith SC, Gutierrez GC, Carolan C, Broadbent PJ, Robinson JJ, Wilmut I, Sinclair, KD. Epigenetic changes in IGFR2 is associated with fetal overgrowth after sheep embryo culture. Nat Genet 2001, 27: 153154.

[26] Dean W, Bowden L, Aitchison A, Klose J, Moore T, Meneses JJ, Reik W, Feil R. Altered imprinted gene methylation and expression in completely ES cell-derived mouse fetuses: association with aberrant phenotypes. Development 1998, 125: 2273-2282.
[27] Chavatte-Palmer P, Heyman Y, Richard C, Monget P, LeBourhis D, Kann G, Chilliard Y, Vignon X, Renard JP. Clinical, hormonal and hematological characteristics of bovine calves derived from nuclei from somatic cells. Biol Reprod 2002, 66: 1596-1603.

[28] Chavatte-Palmer P, Remy D, Cordonnier N, Richard C, Issenman H, Laigre P, Heyman Y, Mialot JP. Health status of cloned cattle at different ages. Cloning Stem Cells 2004, 6: 94 100.

[29] Pace M, Augenstein ML, Betthauser J, Childs JM, Eilersten K, Enos J, Forsberg E Golueke P, Graber D, Kemper J, Koppang RW, Lange G, Lesneister TL, Mallon KS, Mell GD, Misica PM, Pfister-Genskow M, Strelchenko NS, Voelker GR, Watt SR, Bishop MD. Ontogeny of cloned cattle to lactation. Biol Reprod 2002, 67: 334-339.

[30] Enright B, Taneja M, Schreiber D, Riesen D, Tian XC, Fortune JE, Yang X. Reproductive characteristics of cloned heifers derived from adult somatic cells. Biol Reprod 2002, 66: 291-296.

[31] Lanza R, Cibelli J, Faber D, Sweeney RW, Henderson B, Navala W, West MD, Wettstein PJ. Cloned cattle can be normal and healthy. Science 2001, 294: 1893-1894.

[32] Walsh M, Lucey J, Govindasamy-Lucey S, Pace MM, Bishop MD. Comparison of milk produced by cows cloned by nuclear transfer with milk from non cloned cows. Cloning Stem Cells 2003, 5: 213-219.

[33] Takahashi S, Ito Y. Evaluation of meat products from cloned cattle: biological and biochemical properties. Cloning Stem Cells 2004, 6: 165-171.

[34] Shimozawa N, Ono Y, Kimoto S, Hioki K, Araki Y, Shinkai Y, Kono T, Ito M. Abnormalities in cloned mice are not transmitted to the progeny. Genesis 2002, 34: 203-207. 